\title{
Pengaruh Media Sosial TikTok Terhadap Pola Belajar Mahasiswa
}

\author{
Hayun Setiawan $^{\mathrm{a}}$, Hermalia Oktaviana ${ }^{\mathrm{b}}$, Fannya Di Derdya Andawas ${ }^{\mathrm{c}}$, Muchamad Noval Zulkarnaen ${ }^{\mathrm{d}}$, Winni Saripah ${ }^{\mathrm{e}}$ \\ a,b,c,d,e Universitas Sangga Buana YPKP, Bandung \\ hayuns@usbypkp.ac.id
}

\begin{abstract}
ABSTRAK
Perkembangan sosial media dari waktu ke waktu terus menjadi sorotan terhadap khalayak dalam dan luar negeri, itu selaras dengan perkembangan zaman yang terus melesat karena terciptanya hal-hal baru tak terkecuali dalam sosial media. Perkembangan sosial media terus menjadi hal penting dalam sosial manusia untuk perkembangan perubahan dari sebelum-sebelumnya dan menjadi asumsi publik itu sendiri. Sosial media saat ini dikuasi oleh para remaja-remaja yang mengikuti trend terbaru perihal sosial media dan salah satu sosial media yang saat ini sedang menjadi sorotan dan digemari banyak orang terutama oleh remaja adalah Sosial media tiktok yang sedang menjadi santapan oleh semua orang, terutama oleh para remaja mahasiswa yang mengikuti perkembangan zaman dan perkembangan tiktok yang masuk ke semua belahan dunia tak terkecuali Indonesia.
\end{abstract}

Saat ini pengguna tiktok sudah mencapai 100 jt+ dan mendapatkan 4,4 bintang serta 9 juta ulasan di aplikasi playstore ataupun appstore. Banyak nya penggunaan tiktok saat ini membuat perubahan pengaruh terhadap mahasiswa itu sendiri. Tiktok sendiri salah satu platform media sosial yang perkembangan nya paling cepat di dunia, dalam aplikasi tiktok terdapat animasi-animasi ataupun editing yang digunakan penggunanya untuk mendeskripsikan hal-hal yang ada di sekitaran mereka dengan membuat beragam video dan foto.

Di kalangan mahasiswa tiktok sudah sangat tidak asing dan sudah menjadi konsumsi guna membuat konten-konten tertentu, pria dan wanita sama-sama menggunakan tiktok dalam kehidupan sehari-harinya, tentu ini menjadi pengaruh yang sangat serius terhadap pola belajar yang dilaksanakan.

Kata kunci : Tiktok, Semangat belajar, Mahasiswa

\begin{abstract}
The development of social media from time to time continues to be in the spotlight for both domestic and foreign audiences, it is in line with the times that continue to accelerate because new things are created, including in social media. The development of social media continues to be important in human society for the development of changes from before and becomes the assumption of the public itself. Social media is currently dominated by teenagers who follow the latest trends regarding social media and one of the social media that is currently in the spotlight and is favored by many people, especially teenagers, is Tiktok social media which is being eaten by everyone, especially by teenage students who keep up with the times and the development of tiktok that have entered all parts of the world, including Indonesia.
\end{abstract}

Currently, Tiktok users have reached $100 \mathrm{M}+$ and received 4.4 stars and 9 million reviews on the Playstore or Appstore application. The many uses of tiktok nowadays make a change in influence on students themselves.Tiktok itself is one of the fastest growing social media platforms in the world, in the Tiktok application there are animations or editing that users use to describe things around them by making various videos and photos.

Among college students, Tiktok is very familiar and has become a consumption to create certain content, men and women both use tiktok in their daily lives, of course this is a very serious influence on the learning patterns carried out.

Keywoards : TikTok, Eager to Learn, College Students

\section{PENDAHULUAN}

Perkembangan sosial media dari waktu ke waktu terus menjadi sorotan terhadap khalayak dalam dan luar negeri, selaras dengan perkembangan zaman yang terus melesat karena terciptanya hal-hal baru tak terkecuali dalam sosial media. Perkembangan sosial media terus menjadi hal penting dalam sosial manusia untuk perkembangan perubahan dari sebelumnya dan menjadi asumsi publik itu sendiri. Sosial media saat ini dikuasai oleh para remaja-remaja yang mengikuti tren terbaru perihal sosial media dan salah satu sosial media yang saat ini sedang menjadi sorotan dan digemari banyak orang terutama oleh remaja adalah sosial media tiktok, terutama oleh para remaja mahasiswa yang mengikuti perkembangan zaman dan perkembangan tiktok yang 
masuk ke semua belahan dunia tak terkecuali Indonesia. Saat ini pengguna tiktok sudah mencapai $100 \mathrm{jt}+$ dan mendapatkan 4,4 bintang serta 9 juta ulasan di aplikasi playstore ataupun appstore.

Di kalangan mahasiswa tiktok sudah sangat tidak asing dan sudah menjadi konsumsi guna membuat kontenkonten tertentu, pria dan wanita sama-sama menggunakan tiktok dalam kehidupan sehari-harinya, tentu ini menjadi pengaruh yang sangat serius terhadap pola belajar yang dilaksanakan. Pengaruh yang diberikan tentu memiliki ketajaman dan perubahan terhadap pola belajar individu tersebut, lalu apa yang salah. Dalam kasus ini tentu kedua nya mempunyai peranan penting dalam menggunakan nya tidak ada yang salah dan tidak ada yang benar, namun semua tergantung kepada kepribadian yang kita lakukan dan deskripsikan terhadap aplikasi tiktok tersebut.

Bagaimana cara kita mengatur belajar agar tetap seimbangan dengan penggunaan media sosial yang kita miliki, terutama aplikasi tiktok yang menjadi kasus baru dalam pengaruh dalam pola belajar yang dilakukan. Pengaruh yang diberikan tentu beragam sesuai dengan apa yang kita deskripsikan dalam aplikasi tiktok tersebut, mulai dari hal baik sampai menggunakan nya di luar batas dan mendapatkan respon negatif dari kalangan pengguna media sosial lainnya. Ketika kita menggunakan media sosial tiktok dengan membuat konten sebuah video atau lainnya kita dengan mudah nya membagikan konten tiktok tersebut ke dalam sosial media lainnya seperti Instagram, Facebook, WhatsApp serta sosial media lainnya. Dengan membuat konten dalam tiktok tentu kita akan mendapatkan respon yang beragam dan mendapatkan jumlah like yang tertera dalam aplikasi tiktok tersebut. Beragam respon terus ditunjukan selama konten menjadi konsumsi publik dalam sosial media tiktok.

Setelah kurun waktu 4 tahun diluncurkan aplikasi tiktok ini juga menjadi sorotan karena digunakan juga oleh publik figur sebagai konten mereka, ini juga salah satu yang mempengaruhi kalangan remaja terutama mahasiswa dalam membuat konten tiktok. Namun ketika mengingat kejadian kebelakang pada juli 2018 aplikasi tiktok ini sempat di blokir di Indonesia, KEMENKOMINFO telah melakukan pemantauan mengenai aplikasi ini selama sebulan dan mendapati banyak sekali laporan yang mengeluh tentang aplikasi tiktok ini. Laporan yang diterima mencapai 2.853 laporan mengenai konten-konten yang ada di tiktok karena banyak sekali konten negatif yang mempengaruhi terhadap anak-anak dibawah umur, akhirnya pada bulan dan tahun yang sama sejak pemblokiran nya satu minggu kemudian tiktok bisa beroprasi kembali diIndonesia banyaknya pihak yang berkontribusi agar tiktok dapat diaktifkan kembali terutama di indonesia, mereka membuat beragam perubahan termasuk menghapus konten negatif, membuka kantor penghubung pemerintahan dan menerapkan batasan usia serta mekanisme keamanan.

Dan saat ini tiktok sudah sangat menjadi hal yang harus ada di setiap ponsel anak-anak muda terutama mahasiswa dan ini tentu menjadi poin penting terhadap pengaruh tiktok terhadap pola belajar mahasiswa.

Banyaknya ketertarikan karena aplikasi tiktok ini juga mudah di unduh dengan gratis di play store ataupun aplikasi lainnya, tentu ini lah yang menjadikan pengguna sosial media tiktok sangat di gemari sampai dapat mempengaruhi pola belajar mahasiswa dalam melakukan pembelajaran. Pembangunan dan 29 | JURNAL DIMMENSI | Vol.2 | No.1 | 2022 
penumbuhan karakter yang merupakan upaya perwujudan mahasiswa dalam menghadapi era modern ini dilatar belakangi oleh realita permasalahan perkembangan yang terjadi saat ini, seperti aplikasiaplikasi sosial media yang diluncurkan, konten-konten sosial media tersebut, dan tujuan diluncurkan nya

\section{METODE PENELITIAN}

Metode yang digunakan dalam penelitian ini adalah metode pendekatan kualitatif dan jenis penelitian deskriptif. Hal ini bertujuan agar peneliti dapat mengetahui pengaruh penggunaan aplikasi tiktok terhadap pola belajar mahasiswa. Penelitian deskriptif berhubungan dengan frekuensi, jumlah, dan karakteristik dari gejala yang diteliti. Oleh sebab itu, studi deskriptif mempunyai berbagai tujuan antara lain : membuat deskripsi secara sistematis, faktual dan akurat tentang fakta-fakta dan sifat-sifat populasi atau objek tertentu (Krisyantono, 2010).

Teknik pengumpulan data yang digunakan dalam penelitian ini adalah dengan kuisioner. Kuisioner dalam penelitian ini berisi tentang, seberapa lama responden menggunakan aplikasi TikTok dalam sehari, Pengaruh

\section{HASIL DAN PEMBAHASAN}

\section{Karakteristik responden}

Berdasarkan hasil kuesioner yang disebarkan kepada mahasiswa dari berbagai universitas di Indonesia, penulis memperoleh data karakteristik responden yang terdiri dari jenis kelamin responden, umur responden, tingkat responden sebagai berikut:

a. Jenis kelamin : banyaknya responden berdasarkan “jenis kelamin" yaitu responden yang berjenis kelamin pria sebanyak 16 orang atau $(30,2 \%)$ dan responden yang aplikasi sosial media tersebut. Kemajuan teknologi informasi dan komunikasi (TIK) dan pemanfaatannya dalam berbagai bidang informasi sangat diperhitungkan dan menjadi suatu hal yang akan menadi pelopor untuk kemajuan-kemajuan lainnya.

penggunaan TikTok dalam pembelajaran, apa saja yang diperoleh dari penggunaan TikTok pada responden, dan pengaruhnya terhadap pola belajar mahasiswa. Karena dampak dari pandemi Covid-19 kuisioner penelitian ini dibuat melalui Google Form dan dibagikan melalui WhatsApp peneliti. Kuisioner ini diisi oleh 53 responden yang merupakan mahasiswa dari beberapa Universitas yang ada di Indonesia.

Variabel bebas dalam penelitian ini adalah media sosial TikTok dan variabel terikat dalam penelitian ini adalah pola belajar mahasiswa.

Dalam kuisioner, peneliti membuat 2 jenis pertanyaan yakni pertanyaan pilihan dan isian. Alasannya adalah agar responden dapat mengisi kuisioner tersebut dengan sejelas mungkin dan serinci mungkin.

berjenis kelamin perempuan sebanyak 37 orang atau $(69,8 \%)$.

b. Umur : sebagian umur responden 16-19 tahun sebanyak 20 orang (37,9\%). Usia responden 20-23 tahun sebanyak 33 orang $(62,1 \%)$. Hal ini menunjukan bahwa dominasi umur pengguna sosial media Tiktok dikalangan mahasiswa diantara umur 20-23 tahun.

c. Tingkat semester : dari 53 responden yang menjadi mayoritas responden 
Yaitu memiliki latar belakang tingkat $\mathrm{V}$ ada 6 orang $(11,4 \%)$, responden

yang memiliki latar belakang tingkat IV ada 27 orang $(51 \%)$, responden

yang memiliki latar belakang tingkat III ada 18 orang (34\%), responden

yang memiliki latar belakang tingkat II ada 2 orang $(3,8 \%)$.

Seperti yang sudah dijelaskan diatas berikut dari beberapa hasil penelitian yang penulis lakukan beserta dengan diagram yang diperoleh.

\section{Jenis kelamin}

53 jawaban

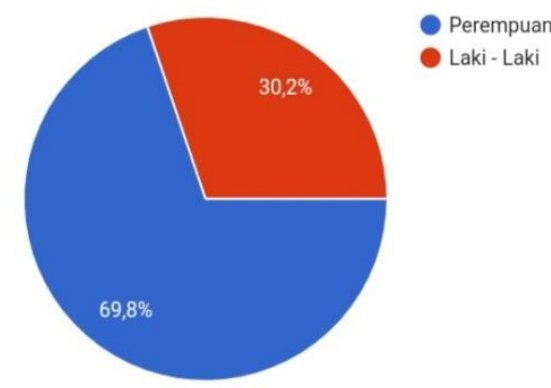

Gambar 3. 1

Sumber: diolah sendiri

Hasil G-Form yang dibagikan kepada mahasiswa mengenai aplikasi tiktok terlihat dalam jumlah persenan mahasiswa yang melakukan survei lebih dari 50 orang di dominasi pengguna berjenis kelamin perempuan sebanyak $69,1 \%$ dan survei pengguna tiktok untuk pria sebanyak 30,2\% dari $100 \%$. terbukti bahwa dalam bermain aplikasi tiktok ini banyak digunakan oleh perempuan dalam survey yang di bagikan dalam pembuatan analisis mengenai aplikasi tiktok.

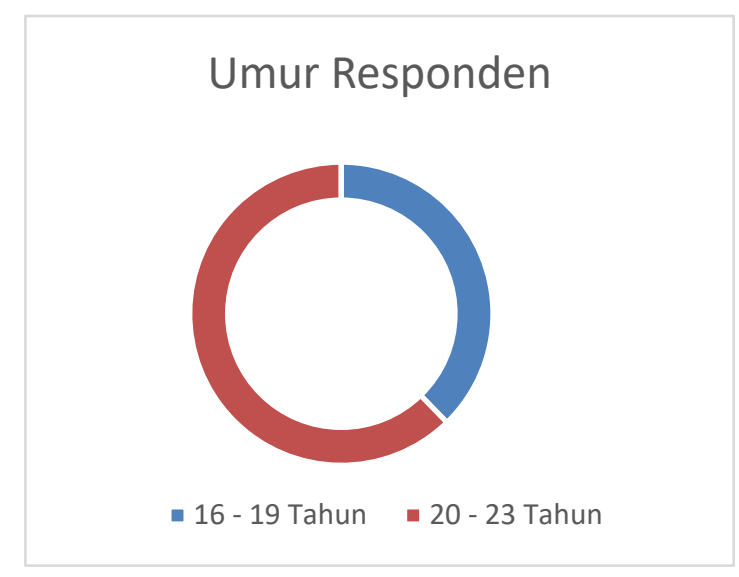

Gambar 3. 2

Sumber: diolah sendiri

Selain itu survey dalam penggunaan aplikasi tiktok ini juga mendapatkan informasi perolehan umur yang bermain aplikasi tiktok ini dari grafik di atas sangat dapat disimpulkan bahwa penggunaan tiktok sejauh ini banyak digunakan oleh kalangan Remaja menuju Dewasa dan membuktikan eksistensi tiktok sangat mendominasi kalangan generasi millenial dan gen Z. Rentan umur yang diperoleh paling banyak adalah dari umur 20-23 tahun.

\section{TINGKAT SEMESTER RESPONDEN}

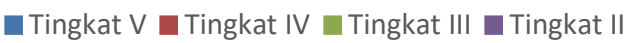

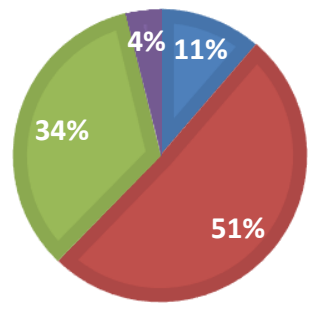

Gambar 3.3 Sumber: diolah sendiri 
Berikutnya adalah survey mahasiswa yang menggunakan aplikasi tiktok ini dari banyak kalangan yang menggunakan tiktok dalam survey yang kami jalankan kepada mahasiswa, banyak diantara nya yang menggunakan dan di dominasi oleh tingkat IV yang memperoleh angka tertinggi yaitu dengan total sebesar $51 \%$ atau 27 orang dari angkatan lainnya.

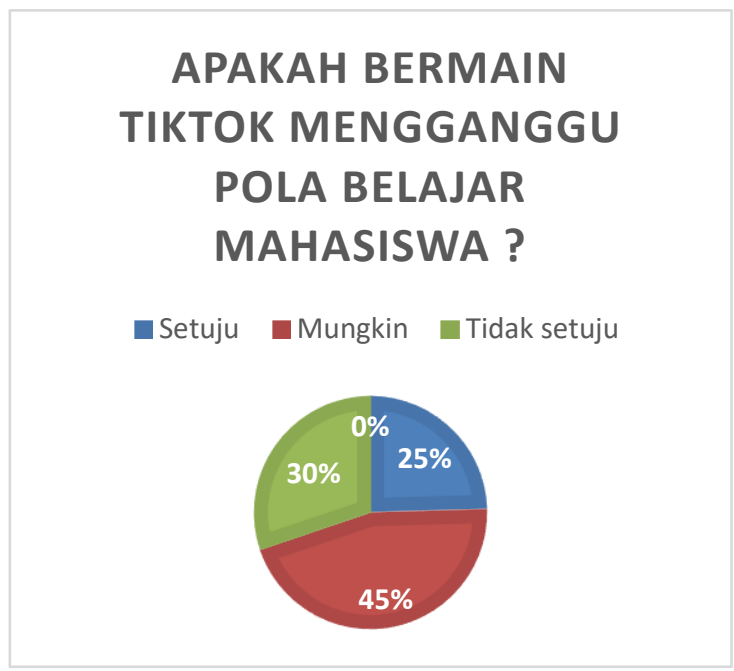

Gambar 3. 4

Sumber: diolah sendiri

Sesuai dengan penelitian analisis yang penulis jalankan dengan membuktikan bagaimana pengaruh tiktok dalam proses pembelajaran mahasiswa saat ini membuktikan bahwa survey analisis grafik pie diatas mencatat sebanyak 45\% mengatakan "MUNGKIN" terhadap pertanyaan yang kami ajukan diatas, ini membuktikan bahwa tiktok bisa saja mempengaruhi proses belajar mengajar kepada mahasiswa dan tentu ini juga memiliki pengaruh yang terjadi kepada mahasiwa tersebut dalam pola belajar, meskipun dalam korelasinya akan mendapatkan jawaban positif atau pun negatif. Jawaban diatas juga mengungkapkan beragam jawaban antara lain setuju dan tidak setuju yang mendapatkan hasil hampir sama atau seimbang.

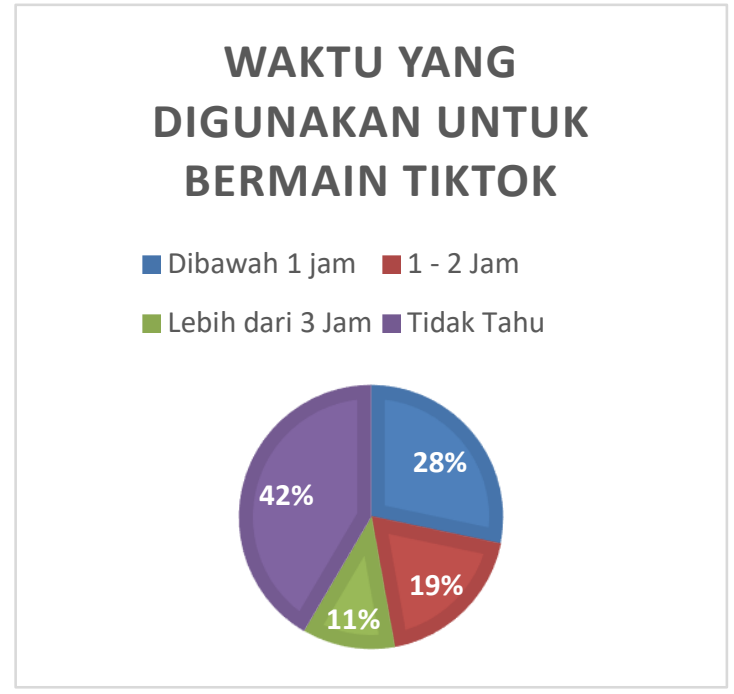

Gambar 3.5

Sumber: diolah sendiri

Lalu bagaimana dengan lamanya para mahasiswa menggunakan tiktok dalam kehidupan nya sehari-hari? 42\% menjawab dibawah tidak tahu atau membuka aplikasi tiktok secara random. Namun juga banyak dari responden yang selalu membuka aplikasi tiktok dalam rentan waktu di bawah 1 jam dan 1-2 jam jika diakumulasikan dalam 1 bulan $(30$ hari $)$ bisa digambarkan para mahasiswa cukup menguras banyak waktu dalam bermain tiktok ini dan tentu dapat mempengaruhi pola belajar mahasiswa itu sendiri. Namun terlepas dari terganggu atau tidaknya bermain tiktok tentu dengan jelas ini akan menjadi kebiasaan yang melekat pada millenial saat ini.

Selain tiktok para mahasiswa juga banyak menggunakan sosial media lain, rata-rata mahasiswa menggunakan sosial media lebih dari 3 , hal ini membuktikan bahwa perkembangan zaman yang terus maju serta teknologi yang semakin canggih membuat banyak orang menjadi kecanduan atau bahkan tidak dapat lepas dari sosial media. Karena pada dasarnya, saat ini banyak komunikasi yang 
dilakukan di sosial media bahkan untuk kegiatan belajar. Sebenarnya hal ini memudahkan para mahasiswa dalam mengakses pembelajaran serta komunikasi jarak jauh, namun banyak juga dari mereka yang menjadi kecanduan sosial media. Namun banyak juga dari responden setuju bahwa sosial media untuk mendapat wawasan baru, berita terkini, dan kejadian viral yang terjadi agar tidak tertinggal informasi.

Manfaat yang dapat diberikat bagi responden sebagai berikut :

a. 34 orang $(63 \%)$ setuju bahwa tiktok dapat digunakan untuk mendapat pengetahuan baru.

\section{KESIMPULAN}

Dalam aplikasi media sosial tik tok banyak berbagai konten video yang ingin mereka buat dengan mudah. Tidak hanya melihat dan menirukan, mereka juga dapat membuat video dengan cara mereka sendiri. Mereka dapat menuangkan berbagai video-video yang kreatif sesuai dengan ide-ide mereka. Tidak hanya mengenai video-video menarik, joget, lipsync dll, mereka juga bisa ikut tantangan-tantangan yang dibuat pengguna lain.

Di kalangan mahasiswa tiktok sudah sangat tidak asing dan sudah menjadi konsumsi guna membuat kontenkonten tertentu, pria dan wanita sama-sama menggunakan tiktok dalam kehidupan sehari-harinya, tentu ini menjadi pengaruh yang sangat serius terhadap pola belajar yang dilaksanakan. Bagaimana cara kita mengatur belajar agar tetap seimbangan dengan penggunaan media sosial yang kita miliki, terutama aplikasi tiktot yang menjadi kasus baru dalam pengaruh



b. 25 orang (25\%) setuju bahwa tiktok dapat digunakan untuk mengetahui berita terbaru

c. 20 orang $(37 \%)$ setuju bahwa tiktok dapat digunakan hanya untuk kesenangan atau hiburan

d. 12 orang $(22,7 \%)$ menjawab tidak tahu atau random saja.

dalam pola belajar yang dilakukan. Pengaruh yang diberikan tentu beragam sesuai dengan apa yang kita deskripsikan dalam aplikasi tiktok tersebut, mulai dari hal baik sampai menggunakan nya di luar batas dan mendapatkan respon negatif dari kalangan pengguna media sosial lainnya.

Dampak TikTok dikalangan remaja menunjukan 3 dari sisi Pemaham;remaja memiliki pemahaman tentang aplikasi TikTok untuk mengekspresikan diri,sarana hiburan, mengeuarkan skill yang dimiliki. Manfaat; tingkat percaya diri meningkat ,tidak perduli perkataan orang lain. Tujuan; hiburan, menunjukan bakat, memperbanyak teman, agar videonya viral.

Konten-konten tiktok yang dibuat tentu sangat mempengaruhi pola pembelajaran yang dilakukan misalnya ada orang yang merasa semangat dan adapula orang yang menjadi 
semakin malas terhadap belajar dan fokus membuat konten-konten di aplikasi sosial media tiktok, tentu ini menjadi himbauan saat ini dan evaluasi terhadap pola yang di terapkan dalam melakukan pembelajaran tersebut.

\section{DAFTAR PUSTAKA}

\section{Jurnal :}

Pratama, S.M, Muclis."Pengaruh Aplikasi Tik

Tok Terhadap Ekspresi Komunikasi

Mahasiswa Universitas Islam Negeri (Uin)

Sunan Ampel Surabaya Tahun 2020”, 2020.

\section{Situs Internet:}

Wikipedia.com,"Tiktok" 20 Agustus 2021

Available: https://id.wikipedia.org/wiki/TikTok

[Accessed 11 Juni 2021]

Gadgettren,com,“Tiktok Sosial Media Berbasis Video Yang Sedang Sangat Populer". 16 Maret 2018

Available:
Ketergantungan menggunakan tiktok menunjukan 1 sisi buruk; akan membuat para penggunanya lupa waktu dan belajar. Ada juga pentingnya tiktok bagi para penggunanya menunjukan 2 sisi positif:bisa mengetahui berita yang lagi trend,viral,informasi terbaru.

https://gadgetren.com/2018/03/16/apa-itu-tik-tok-

video-media-sosial/

[Accessed11 Juni 2021]

Available:

http://download.garuda.ristekdikti.go.id/article.php?arti cle $=1762499 \& \mathrm{val}=18810 \&$ title $=$ PENGARUH $\% 20$ AP LIKASI\%20TIK\%20TOK\%20TERHADAP\%20EKSP RESI\%20KOMUNIKASI\%20MAHASISWA\%20UNI VERSITAS\%20ISLAM\%20NEGERI\%20UIN\%20SU NAN\%20AMPEL\%20SURABAYA\%20TAHUN\%20 2020

[Accessed 11 Juni 2020] 